\title{
Network and Margin: The Case of Chili Supply Chain in Bekasi Regency
}

\author{
Johan Krisnanto Runtuk ${ }^{1}$ dan Nurhayati Surbakti ${ }^{2}$ \\ 1,2) Industrial Engineering Department, Faculty of Technology, President University \\ Jababeka Education Park, Jl. Ki Hajar Dewantara Kota Jababeka, Bekasi 17550, Indonesia \\ Email: ${ }^{1}$ johan.runtuk@president.ac.id, ${ }^{2}$ nurhayati@president.ac.id
}

\begin{abstract}
Chili (cabai rawit) is one commodity that is very significant for people's daily consumption. However, the price of chili often experiences a significant increase. This condition will make the sales of chili decrease dramatically if the price rises. In addition, the margins felt by farmers to sellers of chili in the traditional market are uneven. this is also felt by other vegetable sellers. This research aims to identify the supply chain network of chili in Bekasi Regency. The margin of each stage in the supply chain network is also identified. This research employs descriptive analytical. Descriptive analytics is a preliminary stage of data processing that creates a summary of historical data to yield useful information and possibly prepare the data for further analysis. Data collection method used is by direct observation in Bekasi regency and other locations associated with suppliers of chili, then we employ direct and a phone interview with respondents. The finding shows that there are three main stages in supply chain of chili in Bekasi Regency, namely producer, distributor and consumer. The consumers can buy the product from three channels, that shows the flows of product from producer to consumer. The share of margin in the producer stage for the second flow is lower than the first flow, with the value $56.25 \%$ from $75 \%$, then, the third flow is higher than the second flow but still lower than the first flow, with the value $64.29 \%$.
\end{abstract}

Keywords: chili, supply chain, network, margin

\section{Abstrak}

Cabai (cabai rawit) adalah salah satu komoditas yang sangat signifikan untuk konsumsi sehari-hari masyarakat. Namun, harga cabai kerap mengalami kenaikan yang signifikan. Kondisi ini akan membuat penjualan cabai menurun drastis jika harga naik. Selain itu, margin yang dirasakan petani kepada penjual cabai di pasar tradisional tidak merata. ini juga dirasakan oleh penjual sayur lainnya. Penelitian ini bertujuan untuk mengidentifikasi jaringan rantai pasokan cabai di Kabupaten Bekasi. Margin setiap tahap dalam jaringan rantai pasok juga diidentifikasi. Penelitian ini menggunakan deskriptif analitis. Analitik deskriptif adalah tahap awal pemrosesan data yang membuat ringkasan data historis untuk menghasilkan informasi yang berguna dan mungkin menyiapkan data untuk analisis lebih lanjut. Metode pengumpulan data yang digunakan adalah dengan pengamatan langsung di Kabupaten Bekasi dan lokasi lain yang terkait dengan pemasok cabai, kemudian kami mempekerjakan wawancara langsung dan telepon dengan responden. Temuan ini menunjukkan bahwa ada tiga tahap utama dalam rantai pasokan cabai di Kabupaten Bekasi, yaitu produsen, distributor dan konsumen. Konsumen dapat membeli produk dari tiga saluran, yang menunjukkan aliran produk dari produsen ke konsumen. Pangsa margin pada tahap produsen untuk aliran kedua lebih rendah dari aliran pertama, dengan nilai 56,25\% dari 75\%, kemudian, aliran ketiga lebih tinggi dari aliran kedua tetapi masih lebih rendah dari aliran pertama, dengan nilai $64,29 \%$.

Kata kunci: cabai, rantai pasok, network, margin

\section{Introduction}

West Java region has potential in the agricultural sector which is quite good. Having a fertile soil makes the area west java able to produce vegetable products in good quality. Geographically, the area is fairly spacious western Java. Horticulture commodities cultivated in this region of western Java. Chili (cabai rawit) is one commodity that is very significant for people's daily consumption. In the region of western Java alone, chili commodities may be fairly able to meet the needs of consumers so much in many places. West Java Province is the first large ranking red chili producer with an average productivity level of 14.99 tons per Ha (Gemiharto et al., 2016).

Red chili prices always fluctuate throughout the year (Nurvitasari et al., 2018). It sometimes turns out to be so fantastic. For example, at the beginning of 2019, chili prices have not decreased even in one hundred thousand rupiah. Interestingly, at that time, in several places in western Java, 
it was known that small stalls adjacent to the chili farm location actually did not experience a similar increase. Prices were sold actually very far from the market price that is only the range of twenty to thirty thousand rupiah. This condition certainly raises questions. Tsurayya and Kartika (2015) concluded that fluctuations in production and chilli prices indicate weak coordination in supply chain management. This is also supported by findings from Josine et al. (2018).

The increased price is very unusual; this may be caused by supply chain management settings that are not efficient. Efficient supply chain management can be achieved if the management and supervision of channel relationships conducted cooperatively by all parties involved. The regulations of the supply chain need special attention. A commodity supply chain approaches their chili in West Java especially starts from Bekasi is expected to provide an overview of supply availability as a consideration chili supply chain management for both consumers and the processing industry.

Two basic questions are determined for this research, as follows:

1. How is the network design of the supply chain of chili in Bekasi Regency?

2. How is the supply chain margin in each stage of the supply chain of chili in Bekasi Regency?

\section{Literature Review}

\subsection{Supply Chain Management}

Supply chain management is a set of approaches utilized to efficiently integrate suppliers, manufacturers, warehouses, and stores; so that merchandise is produced and distributed at the right quantities, to the right locations, and at the right time, in order to minimize system wide costs while satisfying service level requirements (Simchi Levi, 2002). Furthermore, Kotzab and Schnedlit (1999) defined SCM practices as a special form of a strategic partnership between retailers and suppliers.

Tan (2002) also recommended that SCM practices include the flow of materials and information and postponement strategy and mass customization. Supply chain management has been one of the main focuses in either physical and digital business until this era. Of course, the primary objectives of a company maximize their company while minimizing the cost, spreading the connection and having a good relationship with the customer. All of the companies have their own strategies to cope with the current situation.

\subsection{Agribusiness and Horticulture}

Indonesia is well known as the largest archipelago and a big agrarian country in the world. In contributing to the national economic building, the agriculture sector has been the main priority. If it observed from any perspectives, the agriculture sector is dominant in the national economy (Widisatriani et.al, 2015). Saragih (1999) suggests three reasons why agriculture is one of the only sectors that might help to rebuild the economy. First, agriculture is one of the main sectors that showed positive growth in the past several years. Even though rice production declined somewhat in 1997 as a result of severe drought, production soon increased again. The agriculture sector's share of real GDP was relatively stable at around 15 to 17 percent between the first quarter of 1994 and the third quarter of 1999. Second, according to Saragih (1999), agribusiness comprises a significant share of non-oil and gas manufacturing value-added, exports, and employment, while it comprises only a small share of non-oil/ gas imports. Third, agribusiness, which consists mostly of small and medium scale enterprises, is generally environmentally friendly and provides income and employment to low-income/ low-skilled workers. Overall, the agriculture infrastructure has the purpose to increase the food agriculture production to reach the food needs, increase the industrial plants and export plants production, creating the agriculture business industry in the country, providing the job, and trying to improve the farmer's income.

As an agrarian country, the horticulture product needs are high enough. The economic potential of some horticulture plants are quite big (Widisatriani et.al, 2015). Horticulture is the commodity that has a bright future with its beneficial comparative and competitive strength in relieving the Indonesia economic aspect further. According to Kurniawan et.al. (2014), horticulture is one of the sectors in agriculture with varieties commodity and needed by society. 


\section{Results and Discussion}

\subsection{Interview Result}

In this study the direct observation (interview) used for data collection method and using the snowballing method for the guide. The observations were done around the Area of Cikarang to Cibitung, some markets and chili sellers were visited in the area. There are some core questions that we ask the seller, the answer they gave us use to inquire more deeply about the topics in our study. The results of the interviewee to several key respondents are summarized as follows:

The farmers which in Blitar and sell the chilies to the collector in Pasar Cibitung with the price Rp 45,000. Sometimes the chilies also get from Garut. It takes around 24 hours to convey the chilies to Cibitung using minimum 10 trucks and it happens every day. For each purchasing, the purchase is around 60 tons of chilies and each truckload 6 tons to be brought. The shipping cost itself is Rp 700/ $\mathrm{kg}$. The relationship between the farmers and collector has been built for 5 years.

The Collector sells the products for around Rp 50,000-Rp 60,000 per kilograms to many buyers in Pasar Cibitung. In this supply chain, the first buyer or agent that has identified is Market Traders in Cikarang Barat and Cikarang Pusat. They buy the products from Pasar Cibitung and transport them using private cars every day. For each purchase, it will be $100 \mathrm{~kg}$ and usually resist only for some days. The unsold and less fresh chilies will be sold to warteg for those who still want to buy. By selling the chilies with the price Rp 60,000 for each kilogram, they get $10 \%$ profit for the share margin profit and the relationship itself has been built for 4 years.

After that, the next agent with the same stage is the Traditional Market in Pasimal, Cikarang Barat. Same with the Market Trader, they get the products from Cibitung but different price which is $\mathrm{Rp} 60,000 / \mathrm{kg}$. Using the private car, it is carried every day for $5-8$ kilograms for each purchase and the chilies will resistant for around 3 days. The unsold chilies for more than 3 days will be sold to half price than usual. The relationship has been built for 10 years.

The last interviewee in the same stage as Market Trader and Traditional Market is the Retailer. This retailer sells vegetables around Cikarang every day. The chili gets from the same source as others, Pasar Cibitung. Using the private motorcycle, the chilies bought every day for only 2 kilograms. He buys it for only around Rp 60,000-Rp 65,000/ kg and sells back with price RP 70,000. Small profit but he has many customers relied on him. The relationship between the Retailer and the Collector has been built for 4 years.

Table 1 below shows the prices of chili per kilogram, as the result of the observation from many sources done from March to August 2019 in Bekasi Regency.

Table 1. Price of chili in each stage

\begin{tabular}{|c|c|c|}
\hline Stage & Buy & Sell \\
\hline Farmers & - & Rp 45,000 \\
\hline Collector & Rp 45,000 & Rp 50,000-Rp 60,000 \\
\hline Market Trader & Rp 50,000 & Rp 60,000 \\
\hline Traditional Market & Rp 60,000 & Rp 80,000 \\
\hline Retailer & Rp 60,000-Rp 65,000 & Rp 70,000 \\
\hline
\end{tabular}

\subsection{The Supply Chain Network Identification}

After we observed and interviewed key respondents, the flows of chilies are identified from the supplier to the consumer. There are 4 main key elements which are supplier, producer, distributor and consumer. But in this observation and flow of supply, there will be only 3 main key elements. The supply chain network of chili in Bekasi Regency is depicted in Figure 1. 


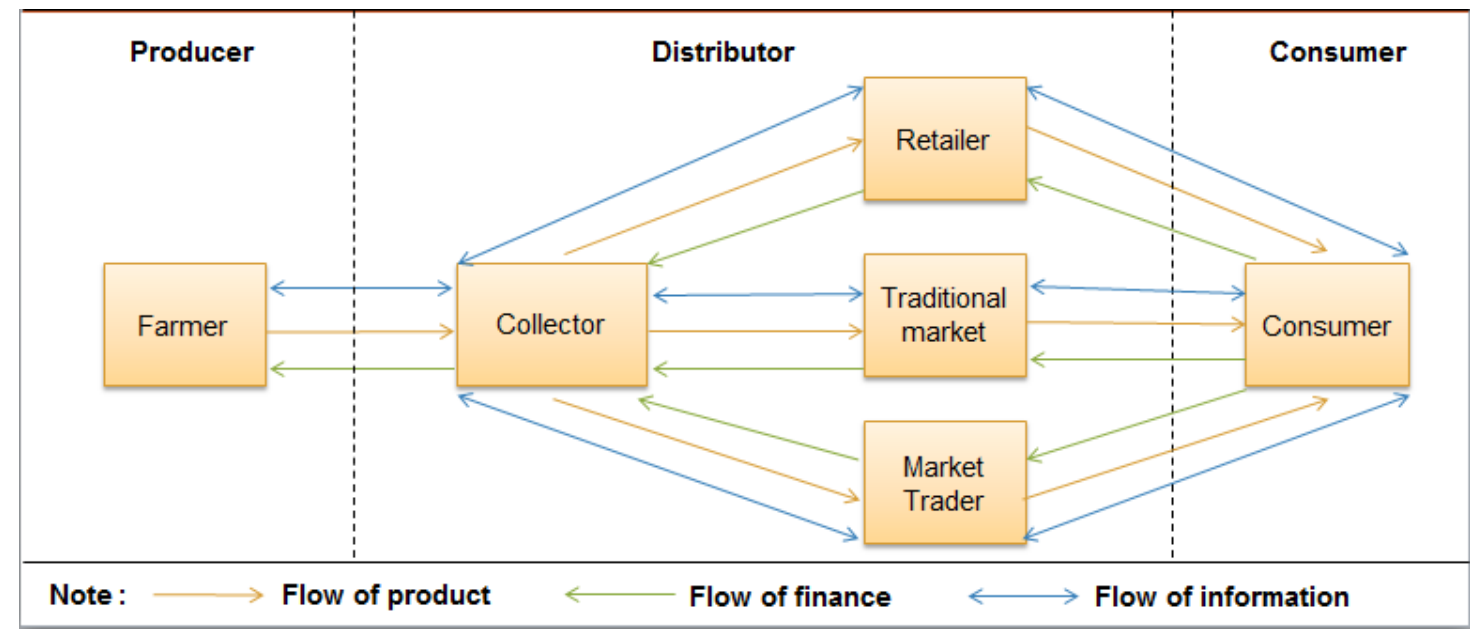

Figure 1. The supply chain network of chili in Bekasi Regency

\subsection{The Margin of Each Stage}

Sales margin shows the difference price of two different stages in the supply chain and literally shows the changes in price between the farmers and the prices paid by the customers. It often used as the indicator of the efficiency for the chain. The value of different flow will be different, depends on the long or short of the flow and the activities that contributed, also the profit wished by the marketing organizations that involved. The share profit margin (SKI) and the share cost margin (SBI) are shown in Table 2.

Table 2. Margin calculation of the first flow of chili supply chain

\begin{tabular}{|c|c|c|c|c|}
\hline \multirow{2}{*}{ No } & \multirow{2}{*}{ Marketing Agencies } & \multirow{2}{*}{ Price (Rp/Kg) } & \multicolumn{2}{|c|}{ Share (\%) } \\
\hline & & & SKI & SBI \\
\hline \multirow[b]{2}{*}{1} & Farmers & & & \\
\hline & selling price & Rp 45,000 & 75 & \\
\hline \multirow{7}{*}{2} & Collector & & & \\
\hline & purchase price & Rp 45,000 & & \\
\hline & labor cost & Rp $\quad 500$ & & 0.83 \\
\hline & transportation cost & $\begin{array}{ll}\text { Rp } & 700\end{array}$ & & 1.17 \\
\hline & packaging cost & Rp $\quad 100$ & & 0.17 \\
\hline & selling price & Rp 50,000 & & \\
\hline & Profit & Rp 3,700 & 6.2 & \\
\hline \multirow{4}{*}{3} & Market Trader & & & \\
\hline & purchase price & Rp 50,000 & & \\
\hline & selling price & Rp 60,000 & & \\
\hline & Profit & $\operatorname{Rp} 10,000$ & 16.67 & \\
\hline \multirow{2}{*}{4} & Consumers & & & \\
\hline & purchase price & Rp 60,000 & & \\
\hline & SM & Rp 15,000 & & \\
\hline \multicolumn{2}{|r|}{ Total } & & 97.83 & 2.17 \\
\hline
\end{tabular}

Based on table 2, the first flow is product flows through the Market Trader seller. The share profit margin will be more focused to be analysed to know the efficiency of the existing chain further on. All the transportation and shipping cost will be included too. From the table above, in this flow, the SKI for each stage is Farmers (75\%) - Collector (6.2\%) - Market Trader (16.67\%). All the numbers calculated and obtained by dividing the profit (selling price for the farmers) divided by the price paid by the consumers. The value of sales margin (SM) for each one kilogram of chili is Rp 15,000 . The total value of the share profit is $97.83 \%$ and the share cost is $2.17 \%$ with the profit in the producer (farmers) stage is $75 \%$. 
Table 3. Margin calculation of the second flow of chili supply chain

\begin{tabular}{|c|c|c|c|c|}
\hline \multirow{2}{*}{ No } & \multirow{2}{*}{ Marketing Agencies } & \multirow{2}{*}{ Price $(\mathrm{Rp} / \mathrm{Kg})$} & \multicolumn{2}{|c|}{ Share (\%) } \\
\hline & & & SKI & $\mathrm{SBI}$ \\
\hline \multirow{2}{*}{1} & Farmers & & & \\
\hline & selling price & Rp 45,000 & 56.25 & \\
\hline \multirow{7}{*}{2} & Collector & & & \\
\hline & purchase price & Rp 45,000 & & \\
\hline & labor cost & Rp $\quad 500$ & & 0.63 \\
\hline & transportation cost & Rp $\quad 700$ & & 0.88 \\
\hline & packaging cost & Rp 100 & & 0.13 \\
\hline & selling price & Rp 60,000 & & \\
\hline & profit & $\operatorname{Rp} 13,700$ & 17.125 & \\
\hline \multirow{4}{*}{3} & Traditional Market & & & \\
\hline & purchase price & Rp 60,000 & & \\
\hline & selling price & Rp 80,000 & & \\
\hline & profit & Rp 20,000 & 25 & \\
\hline \multirow{2}{*}{4} & Consumers & & & \\
\hline & purchase price & Rp 80,000 & & \\
\hline & MP & Rp 35,000 & & \\
\hline \multicolumn{2}{|r|}{ Total } & & 98.38 & 1.63 \\
\hline
\end{tabular}

Table 3 shows the sales margin calculation for the second flow, which is product flows through the Traditional Market seller. All the transportation and shipping cost is also included. As a result, the share profit in the producer stage for the second flow is lower than the first flow, with a value of $56.25 \%$. From the table above, in this flow, the SKI for each stage is Farmers (56.25\%) - Collector $(17.125 \%)$ - Traditional Market (25\%). All the numbers calculated and also obtained by dividing the profit (selling price for the farmers) divided by the price paid by the consumers. The value of sales margin (SM) for each one kilogram of chili is Rp 35,000, higher than the previous flow. The total value of the share profit is $98.38 \%$, again higher than the previous flow and the share cost is $1.63 \%$ with the profit in the producer (farmers) stage is $56.25 \%$. The total obtained profit value is higher than the first flow and the cost is also lower, but in the producer stage, the share profit is lower that means the consumers pay higher cost to buy the chili in this supply chain.

Table 4. Margin calculation of the third flow of chili supply chain

\begin{tabular}{|c|c|c|c|c|}
\hline \multirow{2}{*}{ No } & \multirow{2}{*}{ Marketing Agencies } & \multirow{2}{*}{ Price $(\mathrm{Rp} / \mathrm{Kg})$} & \multicolumn{2}{|c|}{ Share (\%) } \\
\hline & & & SKI & $\mathrm{SBI}$ \\
\hline \multirow{2}{*}{1} & Farmers & & & \\
\hline & selling price & Rp 45,000 & 64.29 & \\
\hline \multirow{7}{*}{2} & $\begin{array}{l}\text { Central Market } \\
\text { Traders }\end{array}$ & & & \\
\hline & purchase price & Rp 45,000 & & \\
\hline & labor cost & Rp 500 & & 0.71 \\
\hline & transportation cost & 700 & & 1.00 \\
\hline & packaging cost & Rp 100 & & 0.14 \\
\hline & selling price & Rp 60,000 & & \\
\hline & profit & Rp 13,700 & 19.57 & \\
\hline \multirow{4}{*}{3} & Retailer & & & \\
\hline & purchase price & Rp 60,000 & & \\
\hline & selling price & Rp 70,000 & & \\
\hline & profit & Rp 10,000 & 14.29 & \\
\hline \multirow{2}{*}{4} & Consumers & & & \\
\hline & purchase price & Rp 70,000 & & \\
\hline & $M P$ & Rp 25,000 & & \\
\hline \multicolumn{2}{|r|}{ Total } & & 98.14 & 1.86 \\
\hline
\end{tabular}

Table 4 shows the sales margin calculation for the third flow, which is product flows through the Retailer. The result is the share profit in the producer stage for the third flow is higher than the second flow but still lower than the first flow, with a value of $64.29 \%$. From the table above, in this flow, the SKI for each stage is Farmers $(64.29 \%)$ - Collector $(19.57 \%)$ - Retailer $(14.29 \%)$. The value of sales margin (SM) for each one kilogram of chili is Rp 25,000 and the total value of the share profit is $98.14 \%$ with the total of the share cost $1.86 \%$, with the profit in the producer (farmers) stage is $64.29 \%$. 


\section{Conclusions}

This research aims to identify the supply chain network of chili in Bekasi Regency, including the margin in each stage of the supply chain. Several things can be concluded in this research as follows:

1. The finding shows that there are three main stages in the supply chain of chili in Bekasi Regency, namely producer, distributor and consumer.

2. The consumers can buy the product from three channels (through a market trader, traditional market, or retailer), that shows the flows of product from producer to consumer.

3. The share of margin in the producer stage for the second flow is lower than the first flow, with the value $56.25 \%$ from $75 \%$, then, the third flow is higher than the second flow but still lower than the first flow, with the value $64.29 \%$.

\section{Acknowledgement}

This research are supported and funded by the DRPM Kemenristekdikti for Hibah Penelitian Dosen Pemula (PDP) year 2018.

\section{References}

1. Gemiharto, I., Zein, D., and Karimah, K. L. (2016). Evaluasi Model Pemasaran Koperasi Dalam Upaya Penguatan Kelembagaan Ekonomi Masyarakat. Jurnal Manajemen Komunikasi. 1 (1), 57-78.

2. Josine, N.A., Pangemanan, L.R.J., and Pakasi, C.B.D. (2018). Analisis Rantai Pasok Komoditi Cabai Rawit di Kota Manado. Agri-Sosio Ekonomi Unsrat. 14 (1), pp 207-214.

3. Kotzab, H. Schnedlit, V.,(1999). How Supply chain management contributes to the management of supply chain preliminary thought on an unpopular question, in Larson and Paulson (Eds), Building new bridges Logistics, Lund University pp 213-36.

4. Kurniawan, R.D., Suwandari, A., and Ridjal, J.A. (2014). Analisis Rantai Pasokan (Supply Chain) Komoditas Cabai Merah di Kabupaten Jember. Jurnal Berkala Ilmiah PERTANIAN. 9 (9).

5. Nurvitasari, M.E., Suwandari, A., and Suciati, L.P. (2018). Dinamika Perkembangan Harga Komoditas Cabai Merah (Capsicum annuum L) di Kabupaten Jember. JSEP. 11 (1), pp 1-8.

6. Saragih, B. (2001). Agribisnis Paradigma Baru Pembangunan Ekonomi Berbasis Pertanian. Bogor: Pustaka Wirausaha Muda.

7. Simchi-Levi, David, Philip Kaminsky, and Edith Simchi-Levi (2003). Designing And Managing The Supply Chain: Concepts, Strategies, and Case Studies. McGraw Hill. The McGraw Hill Company. New York.

8. Tsurayya, S. and Kartika, L. (2015). Kelembagaan dan Strategi Peningkatan Daya Saing Komoditas Cabai Kabupaten Garut. Jurnal Manajemen \& Agribisnis. 12 (1), 1-13.

9. Widisatriani, A.G., Widyantara, I.W., and Angreni, I.G.A.A. (2015). Manajemen Rantai Pasok Benih Cabai Rawit (Kasus di Yayasan Idep, Desa Batuan Kaler, Sukawati, Kabupaten Gianyar). EJurnal Agribisnis dan Agrowisata. 4 (4), 290-297. 